\title{
Marketing the Institution to Prospective Students - A Review of Brand (Reputation) Management in Higher Education
}

\author{
J.H. Beneke \\ B. BusSc, M. BusSc, Cape Town \\ Senior Lecturer \& Programme Convenor, Marketing section, School of Management Studies \\ Faculty of Commerce, University of Cape Town, South Africa \\ Tel: 27-21-650-4392Ｅ-mail: Justin.Beneke@uct.ac.za
}

\begin{abstract}
This article considers an overview of brand (reputation) management in higher education, with a focus on South Africa. The literature paints a picture necessitating a proactive stance on maximizing the appeal of the institutional brand so as to recruit desirable students and ensure that the institution's strategic goals are achieved. Inherent in this approach is embracing the competitive challenge, effecting internal remedies and thereafter ensuring that all branding elements are cohesively aligned. Findings suggests that just like any other brand, an institutional brand has the effect of reducing perceived risk for consumers (the students) and allowing the institution a degree of stability in the market place. However, marketers of institutional brands are cautioned against the multiplicity effect, whereby the multifaceted brand can prove challenging to manage. Lastly, a South African framework is reviewed as a means to achieve the above.
\end{abstract}

Keywords: Brand management, Reputation, Marketing, Higher education, South Africa

\section{Introduction}

Public tertiary education institutions in South Africa have for decades followed very similar practices in order to entice students to apply to their institution. Until the nineties, attracting the right number, or the right mix, of students was not a priority as state funding - often provided with minimal reporting requirements other than academic performance - ensured a constant stream of income to finance operations. In recent times, that appears to have changed. The national government has insisted on more representative student bodies and has implemented strict budgetary constraints on tertiary educational spending, whilst ensuring that this is more equitably distributed amongst all public higher education institutions.

This has forced both traditional Universities and Universities of Technology to become more proactive and to more carefully manage which students are admitted into their respective institutions - a trend which has also been observed internationally. Owing to competitive pressures, institutions therefore need to become more proactive in their marketing endeavours (Wonders and Gyuere, 1991; Zemsky, Shaman \& Shapiro, 2001) and, in response, many institutions have already turned to corporate principles to run their operation and to recruit their 'customers' (i.e. the students).

Traditionally, most higher education institutions in South Africa have been rather unprogressive in terms of marketing themselves to prospective students (Law, 2002). Arguably, the fundamental reason as to why this may be the case can be found in their heritage. Universities and Universities of Technology throughout South Africa have historically "operated in a protected, regulated market with a steady income" (Hay and van Gensen, 2008, p. 79). This has meant that they have not been exposed to truly competitive enterprise and are not accustomed to competing in an environment where survival, rather than being guaranteed, is a privilege that needs to be earned. To this end, Hay and van Gensen (2008) argue that market orientation, whereby the 'customer' is at the heart of service delivery, has eluded higher education institutions in South Africa for many years.

Additionally, it appears as though few institutions have a comprehensive, institution wide, co-ordinated marketing programme. It would appear that at present, marketing is at best executed on an ad-hoc basis. Yet, an exception to this norm may be the attitude of Universities and Universities of Technology toward their alumni and donor markets. These institutions appear to pay special attention to alumni in the hope that these graduates will act as fine ambassadors for the institution and, possibly more importantly, will provide future funding to the institution in the form of personal donations and/or donations from the companies/organizations at which they are employed. 
The most prominent of players to engage in fully fledged direct marketing initiatives appear to be the private institutions (such as Damelin, Varsity College and Monash University), which are classified as 'for-profit institutions' in the literature and are essentially private companies operating as a business in the higher education sector. These institutions do not benefit from government funding nor do they have the social responsibilities as assigned to public Universities and Universities of Technology. Thus, these companies have been forced to contend with market phenomena from the outset, yet some have thrived in the South African higher education environment and are starting to pose serious competition to well established public institutions.

\section{The Competitive Imperative}

Indeed, institutions face a plethora of issues and challenges in the current era of higher education endeavours. In this respect, institutions are "being urged to provide high quality education, exist as a well-reputed university, achieve enrolment success, improve competitive positioning, provide contemporary and well-designed academic programs, and maintain financial strength" (Cetin, 2003, p. 57). This has forced administrators at institutions of higher education to begin to recognize that they need to function more like a business and market their offerings utilizing sound strategies (Hancock and McCormick, 1996).

Higher education around the world has experienced rapid growth and, under the pressure of obtaining sufficient funds, it has had to become a "big business enterprise" (Liu, 1998:19). Zemsky et al (2001:1) concur with this sentiment: "People talk about markets, whether or not they understand them. Most people are also uncomfortable with what they see, or think they see: students using the power of their purchases to define what they need to learn, faculty and departments overly sensitive to things that sell as opposed to ideas that matter, and administrations adopting policies and practices of businesses in order to make a quintessentially messy endeavour more efficient. Everywhere the byword is competition - competition for students, for faculty, for research dollars, for donors, etc. The market now matters in higher education."

This global situation is no different to that in South African. Here, public institutions are facing changes in government funding methods, globalisation of higher education is bringing new competitors into the fray, and applications from new students at some institutions is actually declining (Tagwireyi, 2000).

International research suggests that these trends, in broad terms, are being reflected worldwide. The trend to acquire a tertiary education has taken hold and minority groups, particularly, are being enticed to enter the higher education market in a quest to empower themselves and better their lives (Parvianinen, 2003).

However, this demand is being met by an adequate supply of tertiary education providers in both the public and private spheres. Mainstay educational providers, for example the larger public institutions, are in fact expanding facilities to accommodate increasingly large intakes of students (Kenyon, 2004), and new players in the higher education market are adopting sophisticated marketing techniques to persuade matriculants to study at their institution instead of the competition. Both sets of parties are effectively competing for the same pool of potential customers and the marketing muscle of 'for-profit' institutions is forcing 'non-profit' institutions to respond accordingly. For instance, Professor Colin Bundy, former Vice-Chancellor at the University of the Witwatersrand, reports that the booming private higher education sector was responsible for the fact that white enrolments at Universities and Universities of Technology fell in five years by 41000 , or 19\%, in the mid nineties (Bundy, 2002).

Furthermore, Newsclip Media Monitoring (2002) reports that specialist education providers such as cookery schools, bible colleges and film colleges are also making inroads into the market and are now attracting interest from a growing number of academic achievers. Historically, this would have been an abnormal scenario as the upper end of the academic achiever spectrum was strongly assumed to attend one of the elite public universities.

As per Newsclip Media Monitoring (2002), figure 1 indicates the pressures that appear to be being exerted on conventional (typically public) academic institutions, and the favourable market sentiment currently enjoyed by specialist institutions.

Figure 1 alludes to the syndrome whereby market forces are placing pressure on traditional tertiary education institutions to adapt to the demands of the market. In some instances, as outlined earlier in this chapter, this has equated to decreased enrolment at certain institutions. It is thought that this may be attributed to an undesirable educational product, or bad marketing thereof. It would appear that these institutions need to transform themselves in order to regain their previously held favourable market status. On the other hand, some innovative tertiary educational institutions, offering new educational products or those which the market has learned to appreciate, are experiencing increased demand and are positively exerting themselves on the market. 
Seemingly, it is no longer a foregone conclusion that students will apply to study at a specific institution because there has always been demand in the past. Shifting demographics, fluctuating student preferences and even changing requirements in the job market are fundamentally affecting the status quo (Wilms and Moore, 1987). Similarly, government funding, research grants and donations from alumni are no longer being taken for granted by institutions, as these are becoming increasingly precious as the competition for such income streams intensifies.

Law (2002), analysing higher education marketing in South Africa, finds that there is large scope for improvement in the marketing programmes being executed and that significant benefits will accrue to those brave enough to be progressive on this front.

\section{Attitudes towards the Commercialisation of Higher Education}

Sociologist Manuel Castells contends that tertiary education institutions fulfil five main functions. These are (a) to select 'dominant elites', (b) to provide these individuals with academic training, (c) to generate new knowledge through research, (d) to link knowledge in the institution to applied contexts through entrepreneurial activities, and (e) to act as part of the ideological apparatus of society (Castells, 2001). In order to achieve the above objectives, institutions need the necessary human capital. This human capital comprises both established academic figures as teachers and advanced researchers, and younger minds as undergraduate students, postgraduate students and junior researchers.

Marketing has typically been employed in higher education for two primary reasons: (a) to attract the most desirable students and, to a somewhat lesser degree, academic and administrative staff (i.e. intellectual resources); and (b) to attract government subsidies, research funding, private donations and grants, etc. (i.e. financial resources). However, it would appear that the practice of marketing in higher education in South Africa is a rather complex issue, where definitions of marketing 'in the field' appear to vary considerably. Although many academic institutions would like to believe that they are practicing true marketing and embracing corporate principles, it is thought that many are in fact falling short of the mark.

According to Ivy (2008), the concept of marketing in higher education is certainly not new. Here, Kotler and Fox (1995, p. 6) probably offer the best description of marketing in this particular sector. They describe the practice as the "analysis, planning, implementation, and control of carefully formulated programmes designed to bring about voluntary exchanges of value with target markets to achieve institutional objectives. Marketing involves designing the organization's offerings to meet the target market's needs and desires, using effective pricing, communication, and distribution to inform, motivate and service the markets."

Ed Ziegler, Director of University Marketing at Rowan University, claims that higher education institutions, unfortunately, possess too narrow a view of the above. He suggests that when institutions use the term 'marketing', they actually mean 'promotion' - brochures, direct mail, advertising, public relations efforts, etc. However, Ziegler contends that "marketing is more than ads and brochures. Marketing is a way of thinking that focuses on understanding and meeting customer needs. What makes marketing so powerful is the market research, planning, and strategy that is done before getting to the promotion stage." (Ziegler, 2002, p. 160).

It is not an uncommon perception of institutions that marketing equates to little more than two factors - "many people think that marketing means selling or advertising" (Perreault and McCarthy, 2005, p. 4). As a result, many administrators tend to use only the promotion elements of marketing like public relations, advertising and personal selling to increase enrolments (Ivy, 2002).

Noble (1986) summarized research which indicated very little progress in the professional management of the marketing programs of colleges and universities. He asserts that these institutions may be promoting selling, but very few are actually practicing marketing. Such work prompted institutions to heed this call and become more progressive. In turn, Buell (1996) noted that many colleges and universities had begun to hire marketing professionals and Mackey (1994) suggested that universities had started using many of the marketing techniques more commonly associated with consumer product markets.

Schwartz (1993) and Rogers (1998) have detailed the aggressive efforts of some leading universities, including Northwestern University and Cambridge University, to market themselves using a variety of promotional tools such as advertising and direct marketing. However, Cetin (2003) questions the extent to which progress has been made to date, instead asserting that tertiary education institutions still suffer from too little marketing.

It would appear that this semi-passive stance by institutions toward adopting a comprehensive marketing strategy, although effective to a degree at present, may have serious short-comings in the future as the higher education industry becomes increasingly competitive (Zemsky et al, 2001). Indeed, it is apparent that the rules of the game 
are being re-written - practices that have historically achieved success have no guarantee of doing so in the future.

Part of the problem seems to emanate from the attitudes held by academics toward the marketing discipline (Kirp, 2004). In this respect, Smith, Scott and Lynch (1995) contend that few academics originate from a marketing background and in most cases do not have a thorough understanding of the discipline. For this reason, they hold a negative attitude toward marketing. Nonetheless, it appears rather ironic that many institutions may preach the virtues of marketing to their business management students, yet fail to realise the implications this has for their own institution.

Johnson (1996, p. 73) produced results that showed disengagement of academics from the process of marketing. She concluded that "some academics will accept the market and with it marketing, albeit perhaps in a rather limited way. Others in varying degrees may see marketing as incompatible with their ideological perspective. Others may accept the pragmatic. Few if any see it as an activity to which they should give any more than nominal attention. None saw it in the wider 'relationship marketing' terms."

Piyushi Kotecha, former CEO of the South African Vice-Chancellors Association (SAUVCA), conducted research on the topic of branding activities of South African higher education institutions. He concluded that "while many academic staff may understand this concept in theory, branding smacks of something vulgar and market related. [...] The sustained myth that surrounds institutions is that branding is not needed when the institution has a solid reputation and long tradition." (Kotecha, 2003, p. 4). Kotecha subsequently suggests the notion that institutions that pro-actively market themselves are seen as admitting to being deficient in some manner. This appears to be a mindset that will need attention before lasting damage is affected.

Kotecha $(2003$, p. 4) contends that "the roots of this perception can be traced back into the origins of the university where it consciously established itself as an institution on the margins of society without ever belonging entirely to that society. It continues to believe that for the university to produce new kinds of knowledge through research, it could not afford to be compromised by outside interests." He does however acknowledge that the above may be a red herring with the real reason being sheer arrogance on the institution's behalf. That recognised, an alternate view, one supported by the author, suggests that institutions are merely conservative by nature. In short, they resist change and are therefore slow to adapt to market conditions.

It is also claimed that the adoption of the marketing concept into an unconventional sector, such as higher education, can create problems, particularly if the meaning of marketing is misunderstood or inappropriately applied. Carlson (1992), Fisk and Allen (1993), and Wonders and Gyuere (1991), amongst others, have recognised the increasingly important role marketing is playing in higher education institutions' efforts to attract new students. Yet, they found that there was a general lack of understanding as to what marketing actually meant.

McGrath (2002) points to further research to assess the marketing landscape in higher education.

Taylor and Darling (1991) surveyed 111 college deans from different academic fields concerning their attitudes, finding that these professionals largely supported the need for marketing, but questioned what impact it had on improving the overall quality of their institutions. Michael et al (1993) interviewed 96 Canadian higher education officials and found that only a minority actively engaged in marketing research and the development of marketing plans. Kittle (2000) surveyed professionals at 59 institutions, focusing on their attitudes toward advertising-related issues such as media usage and the relative importance of different target audience groups.

McGrath (2002, p. 5) concluded that "there seems to be an opportunity to break new ground by investigating which institutional functional area is responsible for marketing efforts in colleges and universities, and then to attempt to measure the perceived effectiveness of these functional areas in implementing marketing efforts".

It is argued by some that the primary function of the higher education marketing team is to build the institutional brand. In this respect, it is thought that the image portrayed by institutions of higher education plays a critical role in the attitudes of the institution's publics toward itself (Landrum et al, 1998; Yavas and Shemwell, 1996). According to Kirp (2004), the institutional brand is synonymous with its reputation - regarded as a prize asset by most prestigious higher education institutions. In a similar vein, Paramewaran and Glowacka (1995) in their study of university image found that higher education institutions need to maintain or develop a distinct image to create a competitive advantage in an increasingly competitive market.

However, much of the institutional branding remains clichéd and highly unoriginal. Where branding does exist, there are a number of common constructs which appear ad nauseam i.e. the ideas of excellence, reputation and 
tradition. It is also quite expected for the imagery to predominantly feature the physical space that the institution occupies (Kotecha, 2003).

Kotecha (2003) suggests that within South Africa, private institutions changed the branding landscape during the 1990s by selling an 'experience' (even a lifestyle) as opposed to old buildings, smiling student faces, and impressive library collections. The rationale behind this approach was to market the institution as a place of both learning (perceived as work) and socializing (having fun). It is thought that this balance became important to recruit students who may have been considering tertiary education as a means to an end, rather than the start of an academic or professional career. Other students may simply have been interested in engaging in tertiary studies to delay the inevitable prospect of having to pursue a full-time job.

Despite the differing viewpoints, it appears that contemporary views suggest that the need for marketing in higher education certainly exists. Underscoring this is the extent to which higher education is becoming commercialized in the literature. For example, Bay and Daniel (2001) contend that universities with a large number of international students are referred to as 'export industries' (Gatfield, 1998), courses are termed 'educational products' (Adler, 1998), new instruction methods such as Internet courses are referred to as 'distribution methods' (Gatfield, 1998), and other institutions are referred to as 'competitors' (Landrum et al, 1998). Furthermore, potential students are sometimes referred to as the 'customer base' (Browne et al, 1998; Licata and Maxham, 1998), returning students are called 'repeat business' (Nichols et al, 1998), and attempts to determine to what extent the institution is meeting the students' perceived needs are related to 'customer satisfaction' (Licata and Maxham, 1998).

Present attitudes toward marketing in higher education appear to be converging around a single idea - love it or hate it, almost every aspect underpinning the continued existence of the institution is affected by the marketing thereof. It would be foolhardy to assume that marketing and the institution are strange bedfellows.

\section{Towards Brand (Reputation) Management}

It would appear that marketers often suffer from the delusion that customers or potential customers actually want a relationship with the organization. In fact, not all customers desire a relationship with an organization, with some individuals more likely than others to form relationships (Barnes, 1994). Deborah Wiltrout of the Admissions Marketing Department at the University of Maryland notes that building a strong institutional brand is, in fact, key to enticing customers into a relationship (Pulley, 2003). This theory is further underscored by De Chernatony and McDonald (2003), who claim that a brand is an imperative relationship lubricant. If customers can be enticed to become passionate about the brand, and if they want to actively be associated with it, they are more inclined to enter into a relationship with the organization. Hence, ideally, the brand should act as a magnet - supplementing relationship marketing efforts and drawing all constituents closer together.

The strategic importance of brand management within the student recruitment function was highlighted by Cosser (2002) in a recent Human Sciences Research Council study, wherein he found the reputation of the institution and/or programme of study to be the most important assessment criterion when a scholar is choosing a place of study. Furthermore, several other authors (e.g. Bulotaite, 2003; Moogan and Baron, 2003; Rolfe, 2003; etc.) have strongly associated the function of brand management with that of student recruitment. If indeed student recruitment is to be optimized through a relationship focus (as advocated by Tapp et al, 2004; Yuille, n.d.), brand management will certainly require investigation.

\section{Benefits of owning a compelling brand}

The American Marketing Association describes a brand as "a name, term, symbol or design or a combination of these items intended to identify the goods and services of one seller or a group of sellers, and to differentiate them from those of the competition" (Keller, 2003, p. 3). "Brands embody dimensions such as the logo, design, smell, shape, sound, colour and communication - these factors all differentiate the brand, although some are often more prominent than others" (Van der Walt, 1995, p. 130).

Achenbaum (1993) differentiates between a product and a brand. In his words, "what distinguishes a brand from its unbranded commodity counterpart and gives it equity is the sum total of consumers' perceptions and feelings about the products' attributes and how they perform, about the brand name and what it stands for, and about the company associated with the brand". This is similarly viewed by Siguaw (1999, p. 49) who proposes the view that a brand gives the consumer something to relate to that is vivid, alive, and more complete than what is conveyed by the general offering. In this sense, "a well-established brand personality can result in increased preference and usage, higher emotional ties to the brand, and trust and loyalty".

Keller (2008) advocates that consumers benefit from brands in a number of noteworthy respects, namely: 
- Brands identify the source of the product

- Brands represent an assignment of responsibility to the producer/manufacturer

- Brands reduce risk

- Brands reduce search costs

- Brands contain a promise, bond or pact with the maker of the product

- Brands are a signal of quality

In particular, higher education brands may be used to send a strong signal to potential students about the quality and credibility of the institution (Thomson, 2002). Potential students may then use these cues to assess the attractiveness of a number of institutions (Utley, 2002). To this end, it is likely that strong higher education brands hold a significant amount of appeal to senior high school scholars, who may aspire to be associated with these brands in the near future.

On the other hand, Keller (2008) also advocates that producers/manufacturers benefit from brands in a variety of noteworthy respects, namely:

- Brands are a means of identifying products in the marketplace, and easing their passage through the supply channel

- Brands are a means of legally protecting unique features

- Brands are a signal of quality level to satisfied customers

- Brands are a means of endowing products with unique association

- Brands are a source of competitive advantage

- Brands are a source of financial returns

In the context of the higher education sector, brands appear to be a means of labeling the quality of graduates (in effect, a seal of approval), establishing pulling power in recruiting students, endorsing the legitimacy of research products, and legally protecting advertising features (e.g. the use of a mountainous backdrop set against the main hall on campus, as used in one institution's brand imagery).

\section{Branding developments in Higher Education}

Higher education institutions appear to be extremely concerned about their standing and image in the marketplace. To this end, their 'name' or reputation often underpins their existence. Recently, administrators at educational institutions are becoming challenged to view the development and execution of marketing and advertising programs as a means of building an institution into a brand, as well as to recognize the implications of branding for the recruitment process (Cook and Fennell, 2001; Rosen, Curran and Greenlee, 1998a; Rosen, Curran and Greenlee, 1998b; Sevier, 2002). This necessitates an overview and analysis of the practices in higher education branding.

McNally and Speak (2002, p. 4) define a higher education brand as "perception or emotion maintained by a buyer or a prospective buyer describing the experience related to doing business with an academic institution with its product and service".

Renelle Shampeny, Director of Marketing, SUNY Empire State College, adds that "if the institution has an awareness problem, either being misunderstood or unfamiliar in the marketplace, a good brand will capture the imagination, illustrating its mission with eye-catching visuals and an unforgettable tagline or slogan". She contends that "the brand should be reflected through publications, ads, billboards, web sites, logo, colour palette, etc. to unify the programs and integrate the communications". Furthermore, she proposes that a good brand should not only resonate with external audiences (thereby burnishing the institution's image), but should also speak to internal audiences (i.e. faculty, staff, students, donors, etc.) and instil pride in the institution (Shampeny, 2003, p. 1).

In marketing terms, the institutional name equates to the brand, and the goal becomes to optimize brand equity. In this respect, Fombrun (1996) introduces the notion of 'reputational capital', which he defines as a form of intangible wealth that is closely related to the concepts of goodwill (accounting terms) or brand equity (marketing terms). Fombrun (1996) asserts that an institution stands at a competitive advantage against its rivals if it has a relatively large amount of 'reputational capital'.

Sevier (2001) considers branding in higher education in terms of brand image and brand loyalty. In this respect, brand image describes the desire of students, donors, and others to use brands as signs of status and success. He 
cites the example of students placing stickers on their cars to advertise the fact that they are proud to be associated with their specific institution. Brand loyalty, on the other hand, indicates a preference for familiar brands and a distinct favouritism toward certain institutional brands. Here, he cites evidence which may be found at sporting events where students are most likely to cheer for their institution's side, even if they are unfamiliar with the team and/or the sport being played.

\section{Perceived Risk in Higher Education Brand Management}

In higher education, prominent institutions appear to be understandably proud of their brands and leverage these in the marketplace to attract financial and intellectual capital. In a nutshell, it seems that these brands are promoted by institutions in the expectation that they will provide a level of certainty to reduce risk for buyers of the educational offerings (i.e. the students themselves).

Stone and Gronhaug (1993) advocate that consumers are receptive to brands due to the fact that they reduce perceived risk. This may manifest itself in six forms: functional risk, physical risk, financial risk, social risk, psychological risk, and time risk.

The functional risk may be interpreted as whether the quality of the services of the institution meets the expectation of the student. Essentially, this concerns the issue of standards and hence the credibility of the educational offering. The student may therefore ask him/herself, "are the academic and administrative standards higher or lower than that anticipated prior to registration?" This question may only be answered after the student has enrolled at the institution and attended classes for a reasonable period of time. However, in the case of academic standards, comprehensive answers may only be made available when the individual begins his/her search for employment. In a study by Warwick and Mansfield (2003), several authors (Admissions Marketing Group, 1985; Krukowski, 1985; Sekely and Yates, 1991; Shank and Beasley, 1998; Widdows and Hilton, 1990) found the quality of academic staff, quality of majors of interest, and overall academic reputation as being the most important factors when prospective students and their parents engage in the process of assessing functional risk.

The physical risk may be expressed as the level of safety on campus. For example, is the campus well protected by security forces? Are the lives of students endangered by those individuals who may wish to disrupt academic proceedings and cause instability on campus? This still appears to be a prominent issue in South Africa, even ten years after the advent of democracy, with disruptions at tertiary education institutions occurring country-wide (e.g. Joseph, 2009; SAPA, 2007). According to Warwick and Mansfield (2003), Broekemier and Seshadri (1999) suggest that elements of the institution such as size, location and even weather are significant in terms of physical risk.

The financial risk entails whether the student, accommodation and/or social activity fees are deemed to be worth the price tag. In South Africa, each institution sets its own fees - these are not directly prescribed by the national government. Due to the fact that tertiary education in South Africa is generally considered to be expensive, it is essential that the prospective student perceives the fees to be 'value for money' or else ensures that these are discounted by bursaries, scholarships, etc. so that their financial input is deemed acceptable. According to Warwick and Mansfield (2003), Chapman (1993) and Shank and Beasley (1998) found cost to be one of the most important factors in the college selection process. Similarly, Freeman (1984) found that financial aid also influenced this process, with the exception of high income (i.e. low to no need) students. Furthermore, Krukowski (1985) advocates that parents may be willing to pay high fees in return for better career opportunities for their children upon graduation, and Koshal and Koshal (1994) deem a religious environment (needed in order to fulfill beliefs) as worthy of a fees premium.

The social risk entails choosing the right institution or the right type of institution. For instance, it may be socially undesirable for exceptionally intellectual individuals to study at a University of Technology, as opposed to a traditional University. This may cause embarrassment with reference to peers and family members, and may be ill advisable for this reason. Owing to the fact that many institutions in South Africa are still classified by some as 'previously black' or 'previously white', it may even be a social taboo for certain students to cross this unofficial ethnic divide. According to Warwick and Mansfield (2003), Clark and Crawford (1992) propose two concepts - academic integration and social integration. The former relates to the degree to which the student achieves academic success, whereas the latter refers to the student's personal and social success. They maintain that both types of integration are important for the student, since the greater the compatibility between the student and institution, the higher the probability that the student will complete the academic programme.

The psychological risk may mean moving away from friends to study in a different city, or may even be interpreted as choosing a particularly demanding degree, which may prove to be too mentally challenging for the 
student. According to Warwick and Mansfield (2003), authors such as Conard and Conard (2000) and Murphy (1981) advocate that an institution's reputation is, arguably, the most prominent influence in terms of minimizing psychological risk However, Conard and Conard's argument appears to lack the required depth and consideration of actual psychological risk factors. Instead, it is proposed that reputation is most important in mitigating functional risk.

The time risk may be expressed as the student being unable to easily transfer between institutions if the chosen option is found to be undesirable. This is due to the fact that the tuition periods of institutions largely coincide with each other, hence trading one institution for another may well add an extra year to the student's studies. In this respect, time risk may also be considered as an opportunity cost. Thus, instead of studying, the student could alternatively be employed in a full- time position earning a regular income. Thus, a student's lifestyle and life stage are also likely to have an influence on the concept of time risk.

\section{Challenges and Pitfalls in Higher Education Brand Management}

Unifying and accentuating the brand is often a challenge, as due to its multifaceted nature it is inherently difficult to manage. According to Wileman and Jary (1997), this is considered to be the 'multiplicity effect' and creates an instability which requires ongoing attention.

De Chernatony and McDonald (2003) acknowledge the challenge of services branding and the notion that the principles of goods branding do not necessarily apply equally to services branding. In essence, they contend that this is too simplistic an approach.

In terms of higher education, "student life is a web of interconnected experiences which overlap and influence student satisfaction" (Elliott and Healy, 2001, p. 2). Sevier (1996), similarly, contends that an institution's product is the sum of the student's academic, social, physical, and even spiritual experiences. However, this inevitably makes the educational offering somewhat difficult to brand.

Kotecha $(2003$, p. 4) proposes that branding is made more complex by the fact that it is difficult to determine what exactly the higher education institution sells. "Does it sell graduates, research or something else?" Figure 2 illustrates Kotecha's view on the influences various people, products and impressions have on the institutional brand.

It is immediately evident, upon consulting figure 2, that the institutional brand is indeed extremely multifaceted and, for this reason, may prove difficult to manage. Those elements affecting the brand include corporate identity, public relations, community involvement, advertising, student support, sponsors and partnerships, research output, signage, staff appearance and attitude, graduate throughput, student reputation and physical buildings.

Thus, it may be argued that when considering a traditional University or University of Technology in South Africa, the following factors, inter alia, have a direct affect on the brand:

- the behaviour of thousands of students and staff members

- the research output by hundreds of academics, scattered over a large range of different disciplines

- the state of the buildings and facilities on campus, as well as the signage thereof (usually controlled by maintenance departments, and therefore out of the hands of marketing departments)

- the advertising efforts of different sections of the institution, as well as the institution as a whole (this is often varied across different academic departments with their own web sites, independent public relations exercises, etc.)

- events and exhibitions staged by different departments (these may include conferences, student competitions, community outreach programmes, etc.)

- $\quad$ student service levels and facilities in different faculties (these often vary significantly according to faculty size and corresponding budgetary constraints)

- graduate throughput may also be influenced by factors such as the interest from prospective students in certain areas of study, the ability of students to pay their fees timeously, the institution's equity and skills development policies, etc.

Cetin (2003) proposes a list of positive image determinants which build the institutional brand, and negative image determinants which detract from the institutional brand. These were developed for use within the Turkish academic sector, but the vast majority of which appear to be universally applicable. This list is depicted in table 1. 
However, whilst this list certainly provides a large number of attributes affecting the brand, the distinction between positive and negative brand determinants appears to be very much specific to the institution. For example, if one considers 'students and their conduct', one institution might have a reputation for attracting diligent students, whilst another may have a reputation for attracting less conscientious students. A further example may be 'rules of campus' - whilst one institution may be respected for the level of discipline instilled in, and practiced by, its students, another institution may be perceived as being too stringent (i.e. not allowing its students the necessary freedom of expression) and thus allowing its rules to add toward its detriment. It is therefore almost impossible to determine, in general terms, into which category an attribute is likely to fall. Nonetheless, Cetin does put forward a comprehensive set of factors that influence the institutional brand.

Another challenge faced by brand marketers in higher education is that pertaining to commercial advertising. To this end, advertising may, in fact, be potentially dangerous when the institution is already well established and respected in the market. Although advertising is generally perceived to be a brand building activity (De Chernatony and McDonald, 2003; Keller, 2003), it may be seen to be counterproductive in the realm of higher education. In this respect, there appears to be considerable skepticism concerning what strong brands have to gain by advertising themselves. This is seen as self-defeating in many circles. The question is then often posed, particularly by academics within the institution itself, "why is it that we need to advertise?" Pulley (2003, p. 31) identifies much resistance within the institutions themselves: "There is a lot of natural resistance, particularly from the faculty who don't want to become too business-focused at the expense of things that make a university unique. There continues to be a debate about how commercial we should be."

\section{Towards a Higher Education Branding Framework}

Hay and van Gensen (2008) propose a model for branding of higher education in South Africa. The model is based on three pillars, namely 'experience economy', 'relevance' and 'external branding'. This is depicted in figure 3 on the following page. The first pillar considers the institution's staff as ambassadors of the brand and, in particular, the cues created by the institution's leadership or hierarchy. Having one's house in order (i.e. having the right people and processes in place) therefore appears conducive to strong brand management. The second pillar considers the institution's relevance in society. This relates to a number of factors including the core offering (e.g. the 'entrepreneurial university' versus the 'research university') and the extent to which the institution embraces corporate citizenship. The external branding pillar entails outward communicative elements such as web site management, public relations exercises, etc. The authors argue that internal factors need to be optimized before the external brand can shine.

\section{Conclusions \& Implications}

In summation, it appears that brand management has a role to play in relationship construction between the institution and key stakeholders, as well as increasing the exposure of the institution in the community it serves. The literature review highlighted a number of salient points. Competitive forces in the higher education sector were found to include changes in government funding methods, globalisation of higher education bringing new competitors into the local market, and more discerning students becoming increasingly selective about institutions at which they enrol. Traditional institutions, accustomed to a surplus of applications on an annual basis, too need to pay attention to market forces which may serve to make or break the future of the institution. Thus, it seems that loyalty toward these institutions is only as strong as the benefit they can provide their stakeholders. This necessitates an elimination of complacency and a firm adoption of the competitive challenge.

Managing the brand (reputation) of the institution has been identified as a priority for any educational institution. The institutional brand is akin to any other sort of brand - it reduces perceived benefit for its customers and accrues stability and financial benefits to the owner of the brand. However, the task of managing an academic brand is considerably more challenging than it might initially appear. Firstly, actively managing the brand smacks of commercialism - something many institutions deliberately avoid. Secondly, the sheer multiplicity effect necessitates many layers of support when considering services-orientated brands such as institutional brands. In this respect, there are a multitude of factors which constitute the brand (e.g. signage at the institution, conduct of its students, research output, etc) and all these need to be sufficiently controlled.

Lastly, Hay \& Gensen's (2008) higher education branding framework has been considered for the practical means through which this model can be utilized to support an institution's brand management endeavours. It is recommended that institutions adopt a multi-tiered approach, including fixing internal factors which will then be filtered down to positively reinforce the external brand. In an environment in which perceptions are reality, effectively brand management simply cannot be overlooked. 


\section{References}

Achenbaum, A. (1993). The mismanagement of brand equity. ARF Fifth Annual Advertising and Promotion Workshop.

Adler, K. (1998). Degree upgrades: a new service, a new market and a new strategy for higher education. Journal of Marketing for Higher Education, 9(1), 11-24.

Admissions Marketing Group. (1985). Define quality. Insights, Boston.

Barnes, J. (1994). Close to the customer: but is it really a relationship? Journal of Marketing Management, 10(7), 561-570.

Bay, D., and Daniel, H. (2001). The student is not the customer - an alternative approach. Journal of Marketing for Higher Education, 11(1), 1-19.

Broekemier, G., and Seshadri, S. (1999). Differences in college choice criteria between deciding students and their parents. Journal of Marketing for Higher Education, 9(3), 1-13.

Brooks, L., and Hammons, J. (1993). Has higher education been using the wrong marketing approach? Journal of Marketing for Higher Education, 4(1/2), 27-48.

Browne, B., Kaldenberg, D., Browne, W., and Brown, D. (1998). Student as customer: factors affecting satisfaction and assessments of institutional quality. Journal of Marketing for Higher Education, 8(3), 1-14.

Buell, V. (1996). The marketing explosion. Marketing and Media Decisions, 21(7), 176.

Bulotaite, N. (2003). University heritage - an institutional tool for branding and marketing. Higher Education in Europe, 28(4), 449-454.

Bundy, C. (2002). Mountain high. The Guardian. [Online] Available: http://education.guardian.co.uk /print/0\%2C3858\%2C4511618-48826\%2C00.html. Dated 01/10/2002.

Canterbury, R. (1999). Higher education marketing: a challenge. Journal of Marketing for Higher Education, 9(3), 15-24.

Carlson, C (1992). The first step of marketing a college or university. Proceedings of the Symposium for the Marketing of Higher Education. American Marketing Association, Chicago, 5-13.

Castells, M. (2001). Universities as dynamic systems of contradictory functions. In: Muller, J. and Cloete, N (eds). Challenges of Globalisation. Maskew Miller Longman, Cape Town.

Cetin, R. (2003). Planning and implementing institutional image and promoting academic programs in higher education. Journal of Marketing for Higher Education, 13(1/2), 57-75.

Chapman, R. (1993). Non-simultaneous relative importance-performance analysis: meta-analysis from 80 college choice surveys with 55,276 respondents. Journal of Marketing for Higher Education, 4(1/2), 405-422.

Clark, S., and Crawford, S. (1992). An analysis of African-American first year college student attitudes and attrition rates. Urban Education, 27(1), 57-80.

Conard, M., and Conard, M. (2000). An analysis of academic reputation as perceived by consumers of higher education. Journal of Marketing for Higher Education, 9(4), 69-79.

Cosser, M. (2002). Student choice behaviour. Human Sciences Research Council, Pretoria.

Daughdrill, J. (1994). Assessment is doing more for higher education than any other development in recent history. In: Stark, J. and Thomas, A. (eds). Assessment and program evaluation. Simon and Schuster Custom Publishing, Massachusetts.

De Chernatony, L., and McDonald, M. (2003). Creating powerful brands, third edition. Butterworth-Heinemann, Oxford.

Elliott, K., and Healy, M. (2001). Key factors influencing student satisfaction related to recruitment and retention. Journal of Marketing for Higher Education, 10(4), 1-11.

Fisk, R., and Allen, J. (1993). Applying marketing techniques to achieve the strategic objectives of educational institutions: A case study. Proceedings of the Symposium for the Marketing of Higher Education. American Marketing Association, Chicago, 70-77.

Fombrun, C. (1996). Reputation: realizing value from the corporate image. Harvard Business School Press, Boston. 
Freeman, H. (1984). The impact of no-need scholarships on the matriculation decision of academically talented students. Proceedings of the Symposium for the Marketing of Higher Education. American Marketing Association, Chicago.

Gatfield, T. (1998). The international product lifecycle theoretical framework and its application to marketing higher education to international countries: an Australian /Asian perspective. Journal of Marketing for Higher Education, 9(1), 1-10.

Gibbs, P., and Knapp, M. (2002). Marketing higher and further education: an educator's guide to promoting courses, departments and institutions. Routledge, London.

Hancock, L., and McCormick, J. (1996). What to crop? Newsweek, 59-67.

Ivy, J. (2002). University Image: The role of marketing in MBA student recruitment in state subsidised universities in the Republic of South Africa. Doctoral thesis, University of Leicester.

Ivy, J. (2008). A new higher education marketing mix: the 7Ps for MBA marketing. International Journal of Educational Management, 22(4), 288-299.

Johnson, H. (1996). Education marketing: for academics, for 'anoraks', for everybody? Proceedings of the Policy, Process and Practice conference, 67-74.

Joseph, N. (2009). CPUT protest turns violent. Independent [Online] Available: http://www.iol.co.za/ index.php?from=rss_South\%20Africa\&set_id=1\&click_id=13\&art_id=vn20090507060507556C505354.Dated 07/05/2009.

Jutkins, R. (1994). Just imagine! Database marketing targets the right customers - and keeps them coming back. Direct Marketing, 12(56), 38-40.

Jüttner, U., and Wehrli, H. (1994). Relationship marketing from a value system perspective. International Journal of Service Industry Management, 5(5), 54-73.

Keller, K. (2008). Strategic brand management - building, measuring and managing brand equity, third edition. Prentice Hall, New Jersey.

Kenyon, S. (2004). Varsities, technikons enrol more students than ever before. Cape Times, Cape Town. Dated 20/01/2004.

Kirp, D. (2003). Shakespeare, Einstein, and the bottom line: The marketing of higher education. Harvard University Press, Massachusetts.

Kittle, B. (2000). Institutional advertising in higher education. Journal of Marketing for Higher Education, 9(4), 37-52.

Klassen, L. (2000). Lots of fun, not much work, and no hassles: Marketing images of higher education. Journal of Marketing for Higher Education, 10(2), 11-26.

Koshal, R., and Koshal, M. (1994). Tuition at PhD granting institutions: a supply and demand model. Education Economics, 2(1), 29-45.

Kotecha, P. (2003). Branding, mergers, and the future of South African higher education. South African Universities Vice-Chancellors Association, Pretoria.

Kotler, P., and Fox, K. (1995). Strategic marketing for educational institutions, second edition. Prentice Hall, New Jersey.

Krukowski, J. (1985). What do students want? Status. Change, 17(May/June), 21-28.

Landrum, R., Turrisi, R., and Harless, C. (1998). University image: The benefits of assessment and modeling. Journal of Marketing for Higher Education, 9(1), 53-68.

Law, W. (2002). The marketing of higher education - dreams versus reality. IMM Marketing Educators Conference, South Africa.

Licata, J., and Maxham, G. (1998). Student expectations of the university experience: levels and antecedents for pre-entry freshmen. Journal of Marketing for Higher Education, 9(1), 69-91.

Liu, S. (1998). Integrating strategic marketing on an institutional level. Journal of Marketing for Higher Education, 8(4), 17-28.

Mackey, M. (1994). The selling of sheepskin. Change, 26(3), 51-52. 
McGrath, J. (2002). Attitudes about marketing in higher education: an exploratory study. Journal of Marketing for Higher Education, 12(1), 1-14.

Moogan, Y., and Baron, S. (2003). An analysis of student characteristics within the student decision making process. Journal of Further and Higher Education, 27(3), 271-287.

Murphy, P. (1981). Consumer buying roles in college choice: parents' and students' perceptions. College and University, 56(Winter), 140-150.

Newsclip Media Monitoring (2003). Matriculant profiles 2002: Media analysis report. News Clip Media Monitoring, Cape Town.

Nichols, J., Orehovec, P., and Ingold, S. (1998). Using logistical regression to identify new 'at-risk' freshmen. Journal of Marketing for Higher Education, 9(1), 25-37.

Noble, T. (1986). Marketing programs at colleges and universities: a progress report. College and University, Summer, 34-42.

Oblinger, D. (2003). Strategic enrolment management: strengthening relationships in higher education, white paper. SAS Institute, North Carolina.

Paramewaran, R., and Glowacka, A. (1995). University image: an information processing perspective. Journal of Marketing for Higher Education, 6(2), 41-55.

Parvianinen, S. (2003). Study finds that 'education pays'. European Foundation for the Improvement of Living and Working Conditions, Dublin.

Peck, H., Payne, A., Christopher, M., and Clark, M. (1999). Relationship marketing: strategy and implementation. Butterworth-Heinemann, Oxford.

Perreault, W., and McCarthy, E. (2005). Basic Marketing: A global managerial approach, fifteenth edition. McGraw-Hill/Irwin, New York.

Pulley, J. (2003). Romancing the Brand. The Chronicle of Higher Education, 50(9), 30-32.

Ravald, A., and Grönroos, C. (1996). The value concept and relationship marketing. European Journal of Marketing, 30(2), 19-30.

Reedy, J., and Schullo, S. (2004). Electronic marketing: integrating electronic resources into the marketing process, second edition. Thomson Learning, Ohio.

Rolfe, H. (2003). University strategy in an age of uncertainty: The effect of higher education funding on old and new universities. Higher Education Quarterly, 57(1), 24-47.

Rosen, D., Curran, J., and Greenlee, T. (1998a). College choice in a brand elimination framework: the administrator's perspective. Journal of Marketing for Higher Education, 8(4), 61-81.

Rosen, D., Curran, J., and Greenlee, T. (1998b). College choice in a brand elimination framework: the high school student's perspective. Journal of Marketing for Higher Education, 8(3), 73-92.

SAPA. (2007). Jhb varsity campus shut. News24.com. [Online] Available: http://www.news24.com/Content/SouthAfrica/News/1059/3ffab7adf36e404990bd3f1c9aeebaf2/10-10-2007-1014/Jhb_varsity_campus_shut. Dated 10/10/2007.

Scott, S. (1999). The academic as service provider: Is the customer 'always right'? Journal of Higher Education Policy and Management, 21(2), 193-203.

Sekely, W., and Yates, R. (1991). Multiple positions for an academic institution: a factor analysis approach. Journal of Marketing for Higher Education, 2(1), 87-104.

Sevier, R. (1996). Those important things: what every college president needs to know about marketing and student recruiting. College and University, Spring, 9-16.

Sevier, R. (2001). Brand as relevance. Journal of Marketing for Higher Education, 10(3), 77-96.

Sevier, R. (2002). Building a brand that matters: helping colleges and universities capitalize on the four essential elements of a block-buster brand. Strategy Publishing, Indiana.

Shampeny, R. (2003). Colleges turn attention to branding in competition for new students. The Business Review. [Online] Available: http://www.bizjournals.com/albany/stories/2003/10/27/focus5.html. Accessed 01/06/2004. 
Shank, M., and Beasley, F. (1998). Gender effects on the university selection process. Journal of Marketing for Higher Education, 8(3), 63-71.

Sickler, E. (2003). Higher education's most underutilized marketing tools and tactics. Stamats Applications, $17(1), 1-2$.

Siguaw, J. (1999). The brand personality scale: an application for restaurants. Cornell Hotel and Restaurant Administration Quarterly, 40(3), 48-56.

Smith, D., Scott, P., and Lynch, J. (1995). The role of marketing in the university and college sector. Centre for Policy Studies in Education, University of Leeds.

Stone, R., and Gronhaug, K. (1993). Perceived risk: Further considerations for the marketing discipline. European Journal of Marketing, 27, 39-50.

Tagwireyi, S. (2000). Decline in students hits universities. [Online] Available: http://www.sn.apc.org/wmail/issues/000128/NEWS40.html. Accessed 21/03/2004.

Taylor, R., and Darling, J. (1991). Perceptions toward marketing higher education: do academic disciplines make a difference? Journal of Marketing for Higher Education, 3(2), 17-38.

Thomson, A. (2002). Strong brand is key to recruitment. The Times: Higher Education Supplement, dated $19 / 04 / 2002$.

Utley, A. (2002). Brains, not beer, pull in punters. The Times: Higher Education Supplement, dated 27/09/2002.

Van der Walt, A. (1995). Branding: the good, the bad, and the indifferent. In: Cant, M., Machado, R. and Brink, A. (eds). Marketing Success Stories - Cases and Readings. Southern Book Publishers, Johannesburg.

Warwick, J., and Mansfield, P. (2003). Perceived risk in college selection: differences in evaluative criteria used by students and parents. Journal of Marketing for Higher Education, 13 (1/2), 101-125.

Widdows, R., and Hilton, P. (1990). Assessing the extent to which students' initial expectations of the higher education experience are being met. College and University, 65(1), 85-94.

Wileman, A., and Jary, M. (1997). Retail power plays. Macmillan Press, London.

Wilms, W., and Moore, R. (1987). Marketing strategies for changing times. New Directions for Community Colleges. Jossey-Bass Publishers, San Francisco.

Wonders, T., and Gyuere, J. (1991). Opportunistic marketing in higher education. In: Hayes, T. (ed). New strategies in higher education marketing. Haworth Press, New York.

Yavas, U., and Shemwell, D. (1996). Graphical representation of university image: A correspondence analysis. Journal for Marketing for Higher Education, 7(2), 75-84.

Zemsky, R., Shaman, S., and Shapiro, D. (2001). Higher education as competetive enterprise: when markets matter. New Directions for Institutional Research, No. 111. Jossey-Bass Publishers, San Francisco.

Ziegler, E. (2002). How do you eat an elephant? One bite at a time: A micromarketing approach to student recruitment. Proceedings of the Symposium for the Marketing of Higher Education, American Marketing Association, Chicago, 155-161. 
Table 1. Positive and negative brand determinants

\section{POSITIVE IMAGE DETERMINANTS}

- Students and their conduct

- Faculty

- Administration

- Graduates

- University and industry relations

- Satisfaction of internal and external stakeholders

- Mediatic rector / Leader

- Rules on the campus

- Difference in education and curriculum

- Alumni associations

- Membership to national and international associations

- National and international exchange programs

- Joint ventures and projects

- Research and publications

- Significant building, physical and social facilities

- History of the University

\section{NEGATIVE IMAGE DETERMINANTS}

- Bureaucracy and centralization in educational institutions

- Some education policies and rules governed by the HEC

- Higher education policy in Turkey regarding public and foundation Universities

- Tuition fee policy for public and foundation Universities

- Being newly founded

- Economical issues

- Budget policy

- Media attacks on foundation Universities and its ancillary services and entities

- Unsatisfied internal and external stakeholders

- Deficient resources and facilities

- Quality degradation

- Decrease in research and publications

- Restriction in administrators mobility and planning

- Uncertainty

Source: Cetin (2003, p. 68)

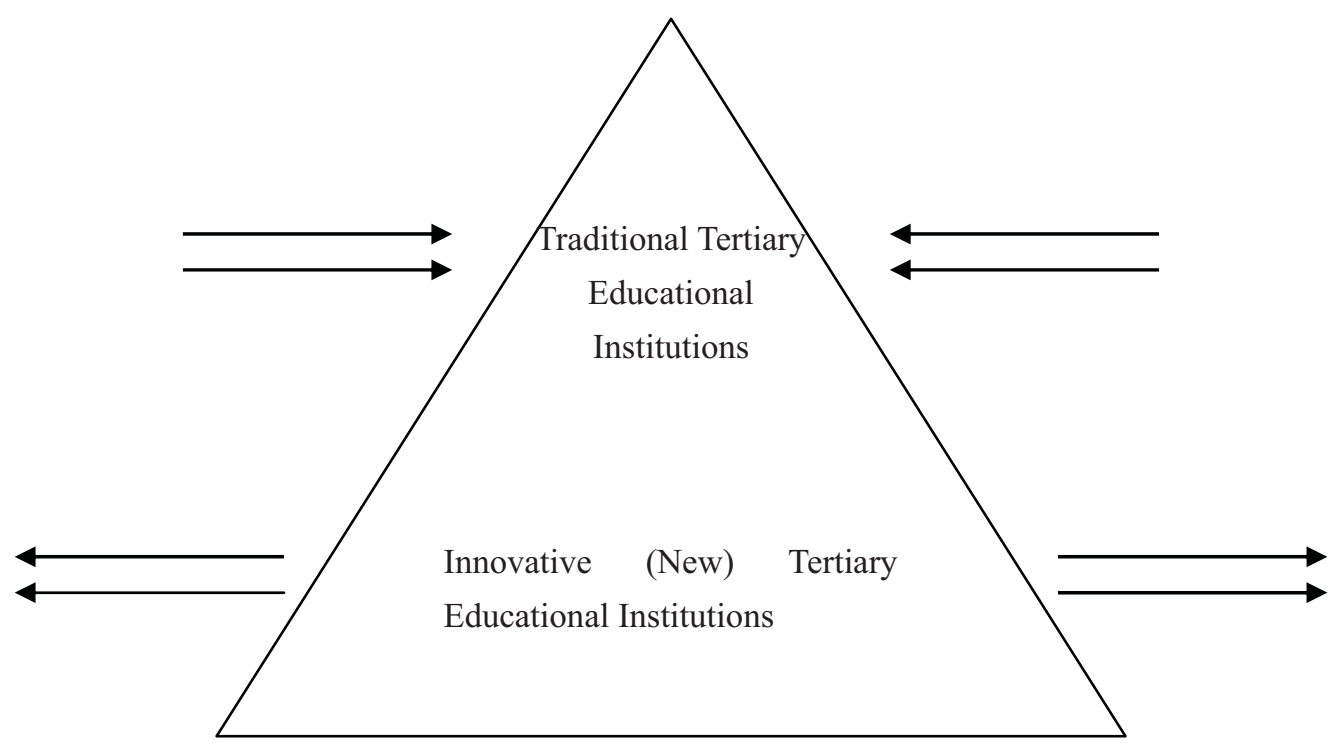

Source: Adapted from Newsclip Media Monitoring (2002)

Figure 1. Forces acting on higher education service providers 


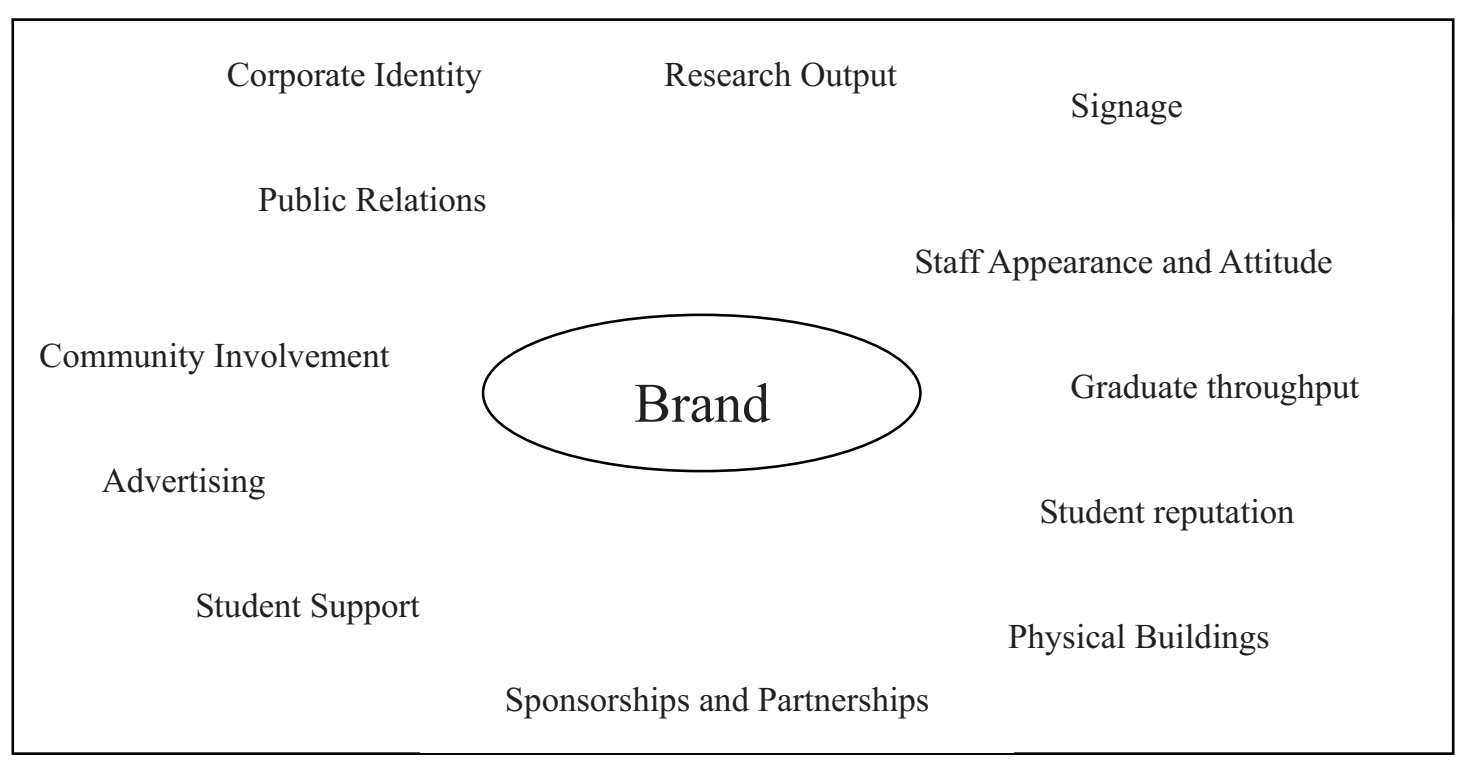

Source: Kotecha (2003, p. 3)

Figure 2. The multifaceted nature of the institutional brand 


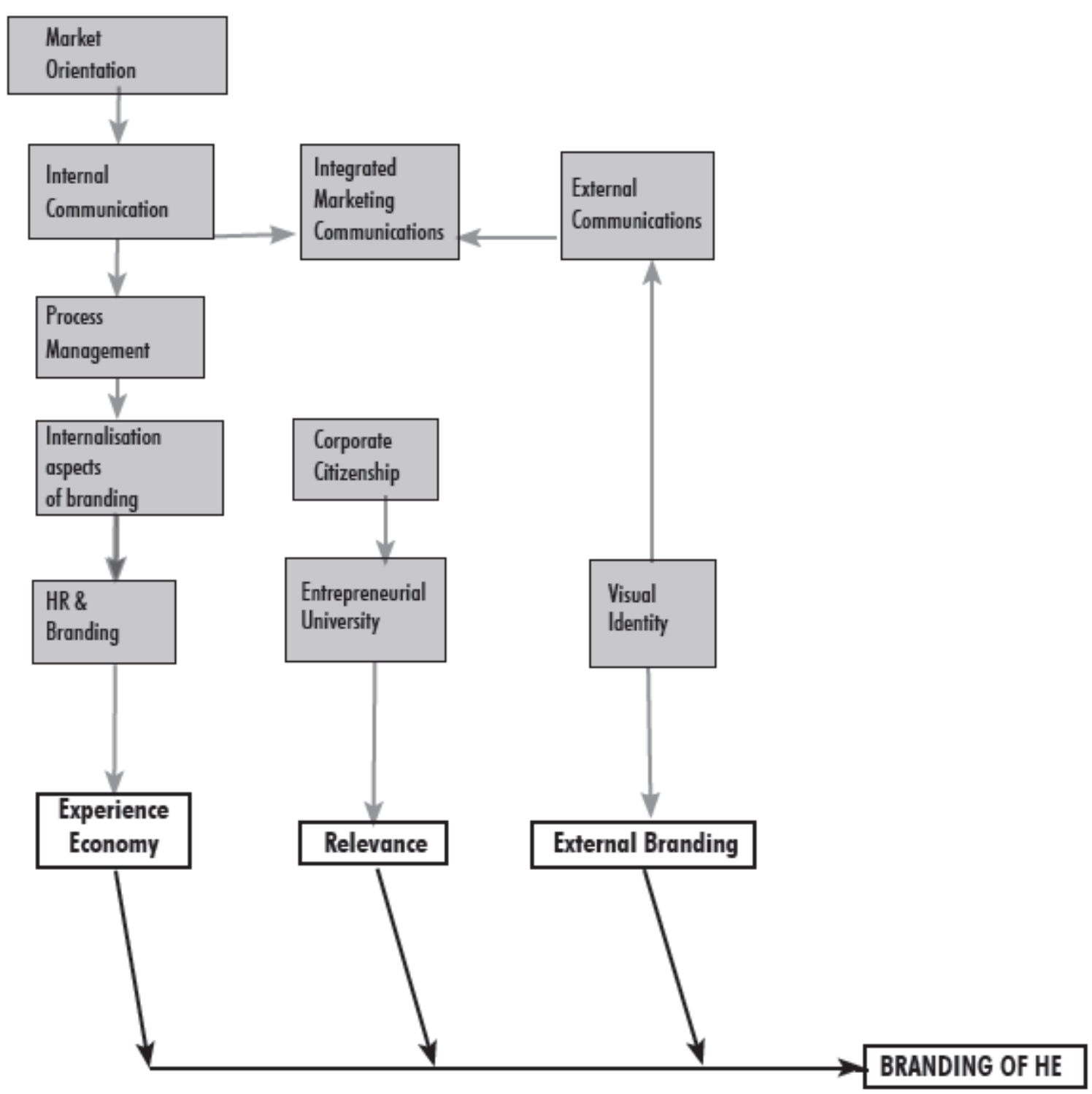

Source: Hay \& van Gensen (2008, p. 80)

Figure 3. Hay \& van Gensen's Higher Education Branding Framework 